Historic, archived document

Do not assume content reflects current
scientific knowledge, policies, or practices. 


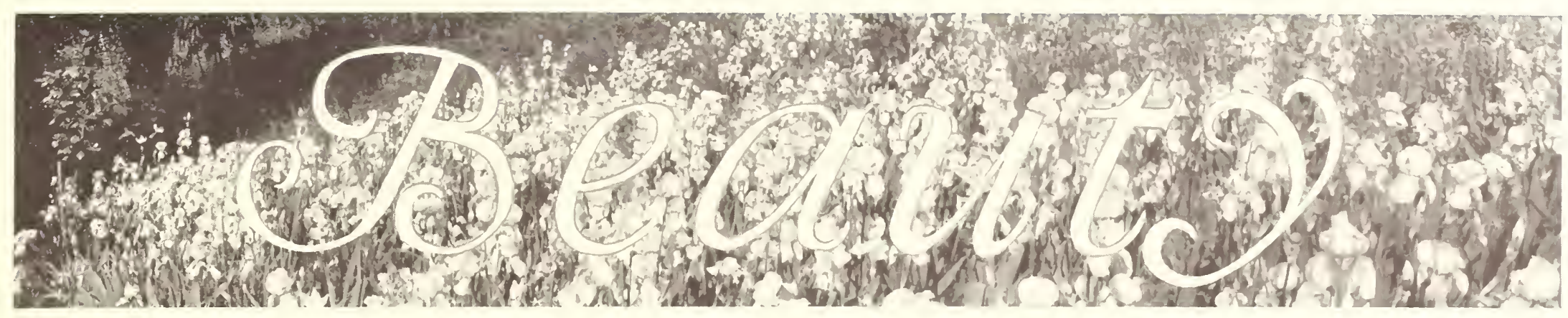

"Iris, Goddess of the Rambow"

VOL. 1

\section{An Announcement}

"Beauty" is rather an ambitious word for such a modest publication as this, but after all, beauty is our stock in trade.

Our first number is devoted to the aristocratic Iris which has, during the past few years, received and earned the admiration of appreciative flower lovers.

Rival of the orchid, the Iris has characteristics which individualize its beauty of color and form. Cultural propagation has developed these characteristics to a point where all who have viewed the results in our gardens are amazed by their beauty. Those pilgrims, who, during the past month. followed the winding roads to our hillside gardens in Berkeley as, sured us, by their praise, that our labor has been worth while. Our gardens are "filled to the brim" with rare Iris creations, and we look forward to sharing their beauty with you. We trust that you will spare us the time to read a few facts about Iris and we would appreciate knowing whether you care to receive any future issues of this little publication. Sincerely,
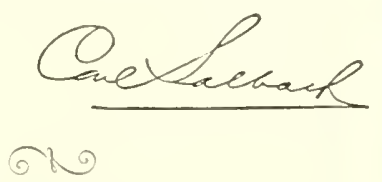

"Queen of the Rainbow"

The popularity which the Iris now enjoys is due to reasons that are just beginning to be understood by flower lovers in general. The work of the modern hybridizers with these flowers has produced such astonishing improvements that the newer Irises rival the exclusive orchids.

\section{Heritage}

We humans inherit, along with a name and what not, certain fundamental characteristics which individualize us each from the other.

Some fortunate ones can point with pride to their family tree and trace its roots deep down into the past.

Here and there may be a branch which might have been the better through a bit of pruning, but on the whole a family-tree is the hall-mark of breeding.

Named Irises are somewhat more fortunate as respects heritage than the average human because of the fact that their propagation has been and is the result of selective breeding.

For that reason their family-tree can be traced back through the years, and their history written without a fear of unearthing a faux pas on the part of an indiscreet ancestor.

Seriously speaking, Irises are truly an aristocratic member of the flower family and deserve the unstinted admiration of every lover of beauty. Irises have earned a place in every garden, whether formal or otherwise and they are so easily grown, need so little care and repay with so much happiness, that the laziest mortal in the world should not begrudge the slight effort for which their growing calls.

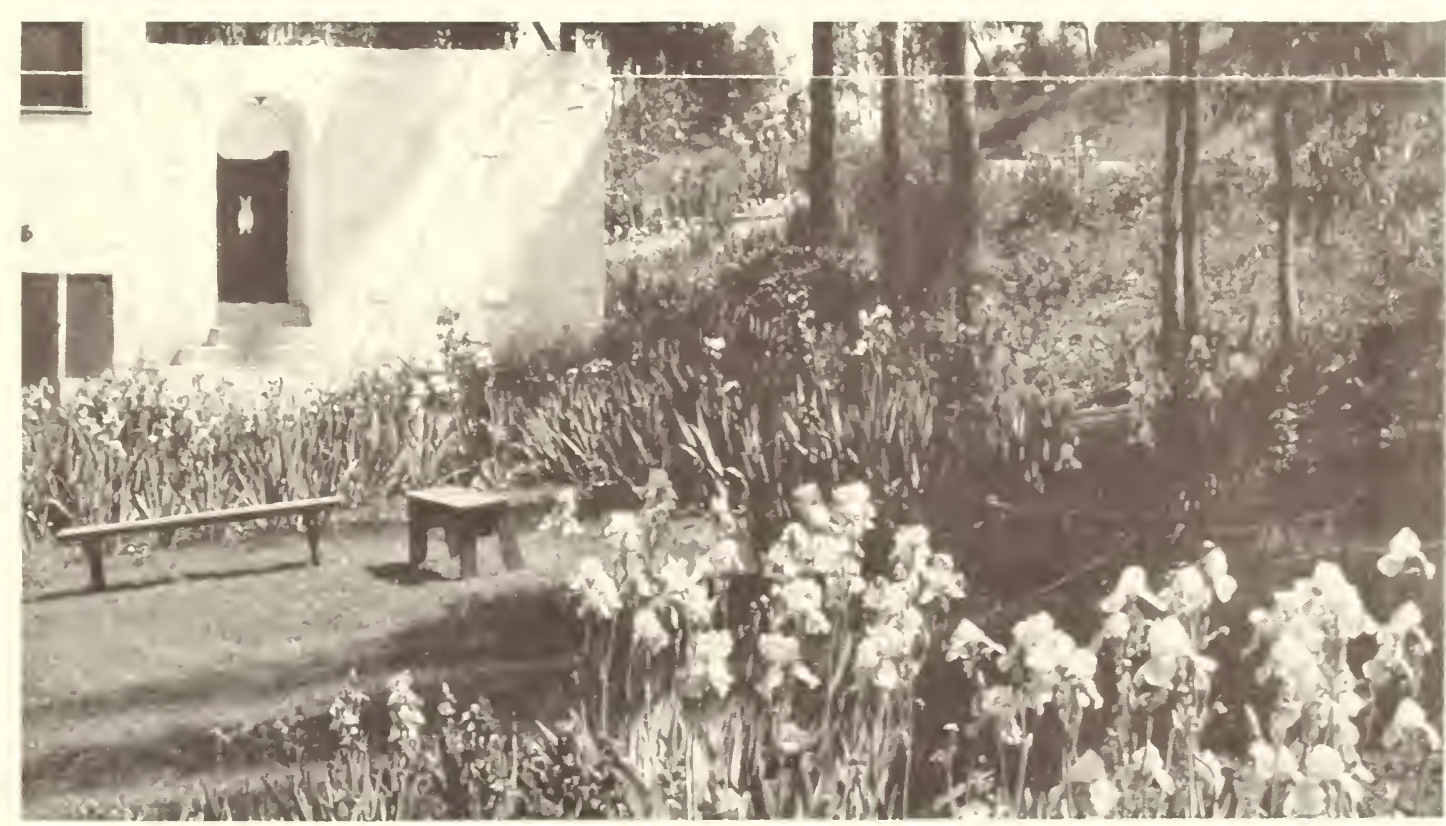

A corner of four acres 


\section{A Short History of Iris}

So called "bearded" Irises (flags) are indigenous to Asia Minor and the Mediterranean regions, consequently they thrive best in comparatively dry sections where there is plenty of sunshine

Albicans, the familiar white flag, was brought to Europe by the Moors when they conquered Spain, and from there it has spread throughout Europe. Collectors, appreciative of the possibilities of Irises, have, for years, exported, imported and interchanged the rarest and most beautiful specimens from all parts of the world.

The result of this interchange has been the propagation of innumerable varieties which in form, size and color offer a wide field from which the flower lover may choose.

The commercial grower segregates those which, in his opinion, promise the greatest values to his customers, and he therefore, is in a position to advise flower lovers as to the best varieties that fit their particular needs. We grow only those specimens which we know are w orthy of a place in your garden, and, consequently, we can recommend from our experience any variety which we offer you.

\section{करo}

\section{Flowers Speak a Universal} Language

It may be of interest to our friends to know that their appreciation of our various creations is shared by flower lovers from all parts of the world.

In South Africa, Alaska, Australia, South Australia, Brazil, Bermuda, Canada, Panama Canal Zone, Cuba, England, France, Germany, Hawaii, Holland, Japan, Mexico, New Zealand, N. S. Wales, Philippine Islands, Porto Rico, are many transplanted specimens from our gardens, and this fact is, naturally, gratifying to us.

Many of our friends have placed reservation orders for later delivery, knowing that unless they do so certain rare varieties which are desired may be sold out.

\section{Starving in the Midst of Plenty}

The case-hardened soul who fails to respond to the beauty of flowers is starving for happiness in the midst of plenty.

Flowers reward you for your care with beauty and with exquisite perfume. They paint your garden with colors such as nature alone can conceive. They bring cheer to your dinner table, charm to your living rooms and hope to the sick room.

They are symbols of sympathy, happiness, admiration and faith, and, fortunately, they strike a responsive chord in the breast of most of us.

Our letter files offer an interesting cross section of flower lovers. Bankers, business men, housewives, business women, garden makers from the four corners of the world, send us their orders, their praise and very often seek our advice.

They ask us regarding the different varieties; which makes the best display? Which are best for cutting? And we answer every one of them.

We want you also to feel that you can call on us at any time for whatever information you need.

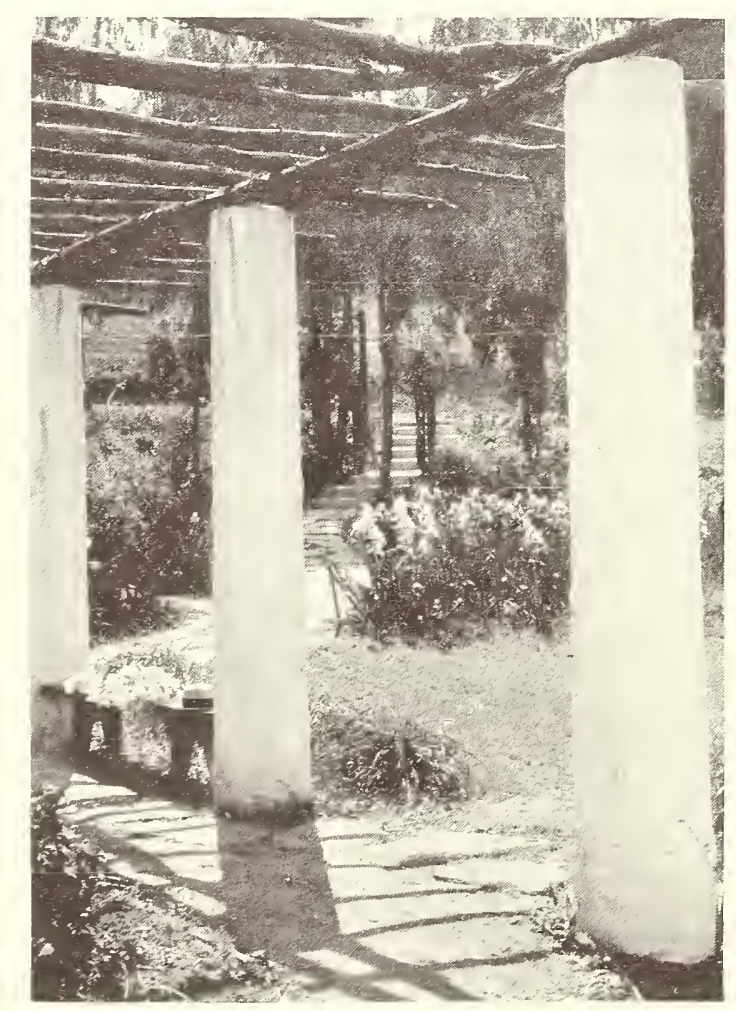

The latchstring is always out

\section{Our Special Offers}

These collections have been care. fully made up to give the most beauty and the greatest variety possible for the amounts invested. The orders will be filled with good strong blooming size rhizomes, will be carefully packed, with cultural directions enclosed, and sent to you prepaid.

All of the named collections will be properly labeled and when sets of three are ordered, the triplicates will be wrapped together.

We are making these low rates on the various collections because we are anxious to give as wide distribution as possible to these wonderful Irises, knowing that we will be repaid in future orders. He can not make any substitution of varieties in the collections.

All orders must be accompanied by money order, check or cash.

These special offers are for de. livery up to September 15, 1927, only.

\section{"The Latch String is Always Out"}

If you had visited our Iris gardens during May you would have carried away with you a colorful impression of beauty that would linger long in your memory.

The astonishing number of varieties grown, the wide range of their coloring, the size of the bloom, were a revelation to many visitors who had not imagined the possibilities of Iirs. The thousands of plants which made this garden possible are now ready to spread their beauty throughout the world. Your share of their beauty is waiting your word to add their glory to your garden.

$$
\text { 6) } 0
$$

\section{Our Summer Gardens}

During the summer months our Dahlias and Gladiolus have transformed our hillside gardens into a riot of color. We wish that all who read this could enjoy their beauty with us. 


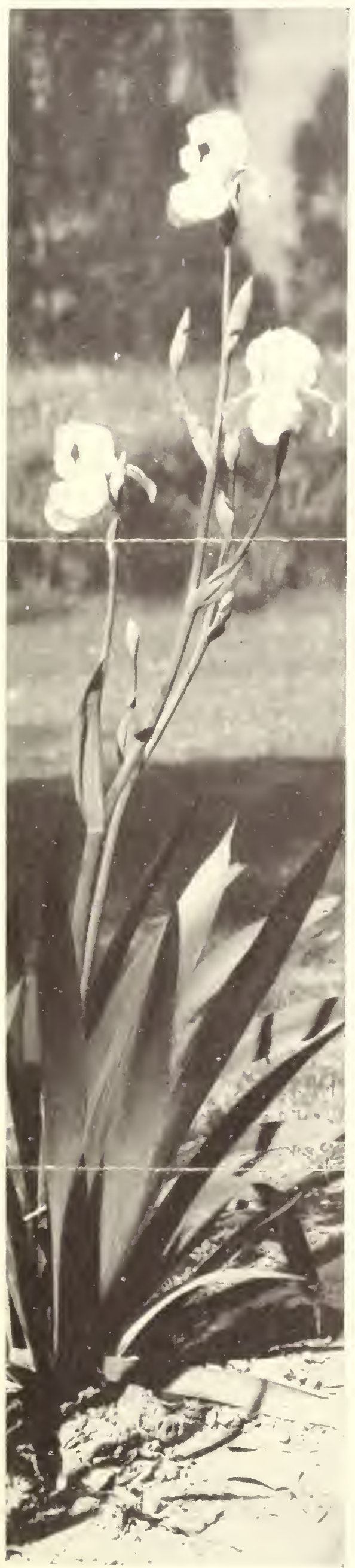

One of the recent Wm. Mohr creations, over 4 feet in height.

\section{Special Iris Collections Shipped Prepaid}

Irises planted in groups of three of a variery offer a more effective planting.
1. j fine irises all clifferent, taken $\log$ stock............ $\$ 1.00$

2. 12 fine irises all different, from our regular 1927 catalog stock

3. 50 fine irises, of at least ten different varicties, and one Esplendido*. Each variety will be labeled (Order filled from regular 1927 (atalog stock.)

4. 100 fine irises, of at least 20 Santa Barbara*. Each variety will be labeled... \$25 00 (Order filled from regular 1927 catalog stock.)

5. 1 Drcam, 1Shekinah, vink vellow 1 Edouard 1 Zenardelli, Michel, rosy blue purple each labeled (Value $\$ 1.75) \ldots \ldots \ldots \ldots \$ \$ 1.50$ 6. 3 sets of collection 5,12 in all $\$ 4.00$

7. 6 pink or rose irises, each labeled Amador* Her Majesty Dejazet Prince Lohengrin* Dream Seminole

(Value $\$ 6.75) \ldots \ldots \ldots \ldots . \$ 5.00$

8. 3 sets of collection 7,18 in all $\$ 12.50$

9. A gold and silver group of 12 irises, each labeled

Afterglow Quaker Lady Grapta Jris King Medallion Shekinah Silverado* Mrs. Neubronner Soledad* Nuee D'Orage Sunset (Value $\$ 8.35) \ldots . . \ldots \ldots . \$ 6.00$ from our resular 1927 catadifferent varicties, and one
10. 3 sets of collection 9, 36 in all $\$ 15.00$

11. 12 choice irises, each labeled Ambassadeur Nancy Orne

Autocrat Prince Lohengrin * Dream Oucen Catcrina Esplencliclo* Rameldo* Lady Foster Ramona* Lent 1. Wil- Souv. de Maliamson dame Gaudi-

(Taluc S14.3\%) $\$ 10.00$

12. 3 sets of collection 11,36 in all.

13. 9 extra choice irises, each labeled Autocrat Madame Cheri Azrael Prince Lohengrin* Coronado* Rajput Delight Santa Barbara*

(Value $\$ 29.50$

$\$ 20.00$

14. 3 sets of Collection 13, 27 in all

$\$ 50.00$

15. A set of 7 ronderful Milliam

Mohr** seedlings, each labeled

Argentina Ramona

Esplendido Rosado

Frieda Nolnr Santa Barbara Ramcldo

(Value 5.50 .50 )

$\$ 40.00$

16. Collection 15, with William Mohr* sin all $\$ 60.00$

17. 3 sets of Collection 13, 27 in all.

18. 3 sets of Collection 16,24 in all.

$\$ 150.00$
Esplendido* $\$ 100.00$

Special Quantity prices on lots of 10-25-100 of one variety.

Special Collection Order Blank

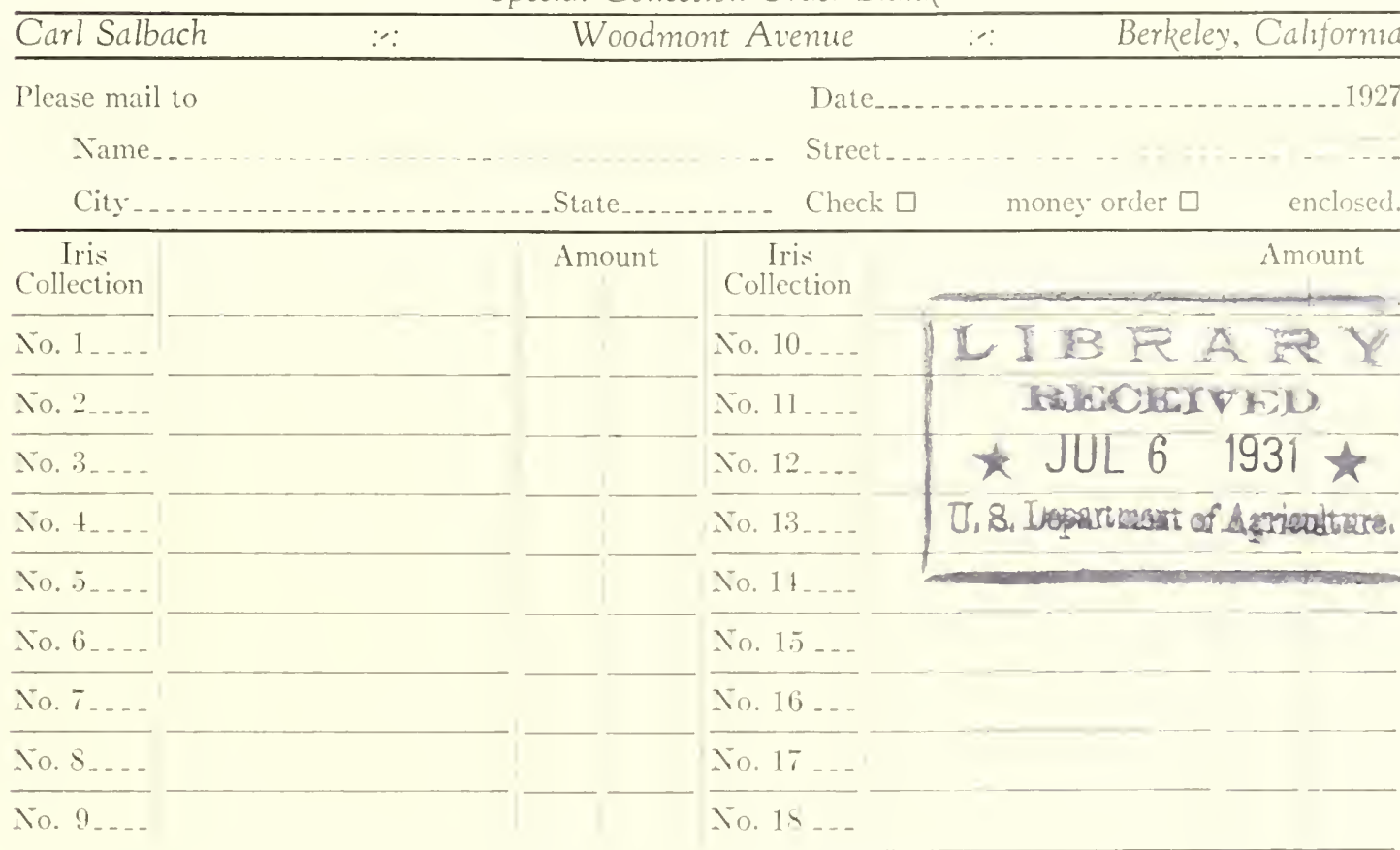

Do you care to receive future issues of "Beauty" yes $\square$ no $\square$ 
Remember, every Iris shipped on the special offers herein contained will be first class stock from varieties listed in our 1927 catalog. Irises planted now will bloom next spring. If you are not pleased with the irises when received you may return them at our expense and we will refund your money at once. If you have any suggestions that will assist in bettering our service, write us. We want your view. point. If you are not interested in "Beauty" please hand this to some other flower lover. Remember, the Irises we send you will be of blooming size and will thrive in your climate.

We want only satisfied customers; that is why we are anxious to serve you well.

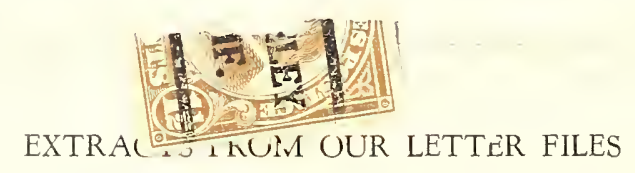

From Pennsylvania.

Allow me to express my gratitude to you for the extra root which you so generously sent me. Many of the irises in my first order are already growing and my satisfaction increases the more I watch them.

From Indiana.

Had a magnificent bloom on Wm. Mohr this Spring and caused a sensation at our Iris Show.

From England.

Of the varieties I got from you I think that the two best were Santa Bar. bara, which is magnificent, and Azulado. Santa Barbara was by many ex. perts considered the finest Iris in the London Show.

From Washington, D. C.

The Iris roots came yesterday by express. The roots were in excellent condition and wonderful in size and vigor.

\begin{abstract}
You may be interested to know that all of the Mohr Irises purchased from you last season came through the winter here in New York in fine shape without any protection. We did not lose a single plant, and had satis. factory blooms on every variety including William Mohr which seems to grow like a weed. We were particularly impressed with Frieda Mohr.
\end{abstract}

From Wisconsin.

Dear Sir:- Thank you very much for the collection of Irises you sent last year. We have enjoyed the beautiful flowers for some time and are still enjoying them. A few did not bloom this year, but I got more than my money's worth.

\section{From Ohio.}

The Irises I got from you last year did just fine. Balboa was great, only I couldn't go to the show; it was through blooming when the show was on.

From Redlands, California.

A Southern California grower writes in June-July, 1927, "Home Acres" as follows:

Of the new things I have had most pleasure in Amerind and Valencia, both of small size but of colors that delight me. William Mohr took the glory as the best thing in the Redlands Show again this Spring and wins me the cup contested for since 1919.

\section{Beauty}

CARL SALBACH,

\section{P. Kent Beattie}

Woodmont Avenue, 